Biol. Stud. 2012: 6(3); 29-38 • DOI: https://doi.org/10.30970/sbi.0603.244

www.http://publications.Inu.edu.ua/journals/index.php/biology

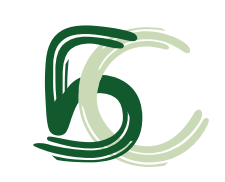

UDC 616-006.441:577.122

\title{
SAPOGENINS ISOLATED FROM THE GREATER CELANDINE (Chelidonium majus L.) SEEDS POTENTIATE A THERAPEUTIC EFFECT OF VINBLASTINE TOWARDS MURINE NK/Ly LYMPHOMA
}

\author{
M. D. Lootsik', M. M. Lutsyk', R. S. Stoika \\ ${ }^{1}$ Institute of Cell Biology, NAS of Ukraine, 14/16, Drahomanov St., Lviv 79005, Ukraine \\ ${ }^{2}$ Danylo Halytsky Lviv National Medical University, 69, Pekarska St., Lviv 79010, Ukraine \\ e-mail: Stoika@cellbiol.Iviv.ua
}

Two treatment schemes (vinblastine and vinblastin in combination with sapogeninlike substance (SLS) isolated from the greater celandine seeds) were applied towards murine NK/Ly lymphoma, and their therapeutic effects were compared. It was revealed that at early stages of tumor growth, there was no significant difference in tumor suppressive effect of two treatment schemes. Potentiating effect of SLS in combined application with vinblastine manifested in delayed results of treatment, i.e. in more then 60 days after inoculation of tumor cells. Clinically, it was expressed in more effective suppression of tumor development after the repeated inoculation of tumor cells, as well as in preventing the appearance of solid tumor nodes, better recovery and survival of the treated mice. Quantitative evaluation of tumor cell damage was performed by using cell morphometry methods which revealed higher proportion of injured cells at the application of vinblastine-SLS mixture. Low toxicity of SLS from the greater celandine seeds, together with its enhancing effect upon the curative action of vinblastine, permits suggesting a perspectiveness of using SLS as an adjuvant in tumor chemotherapy.

Keywords: Greater celandine, sapogenins, vinblastine, lymphoma NK/Ly, treatment.

\section{INTRODUCTION}

Recently, it was shown that steroid and pentacyclic saponins/sapogenins isolated from several medicinal plants, exhibited a significant antitumor activity or potentiate such activity of routinely used antitumor agents [2, 5, 7, 11, 16, 21, 27]. The best results were achieved when the dammarane sapogenins from ginseng (Panax ginseng C.A. Meyer) were used in anticancer chemotherapy at clinical conditions [5, 18, 24].

The greater celandine is a well known medicinal plant, and preparations isolated from its different parts are widely used in both the non-traditional and classic medicine for treatment of different diseases, including the malignant tumors [15, 19]. In previous studies of anticancer activity of compounds from greater celandine, the main attention was focused on specific alkaloids $[4,8,9,19,26]$. Saponins of this plant were frequent- 
ly mentioned but never studied regarding their biological activity at cancer treatment. There was only one reference [10] found, that is devoted to purification and chemical characterization of saponins of the greater celandine, and no detailed study of their biological activity was done.

Earlier we have described the original method of purification of substance with sapogenin properties (sapogenin like substance, SLS) from the greater celandine (Chelidonium majus L.) seeds and presented the results of studying their anti-tumor activity towards experimental murine lymphoma NK/Ly [12,13 ]. It was detected that SLS possessed a weak anti-tumor activity at early application (24 hours after inoculation of tumor cells), and there was no significant treatment effect at the delayed application (5-6 days after tumor inoculation). Taking into account a possibility of potentiating effect of saponins for the anticancer drugs, it was decided to investigate the influence of SLS of the greater celandine towards the therapeutic action of well known anticancer drug vinblastine during their combined application in the NK/Ly lymphoma-bearing mice. Vinblastine was shown to be an effective drug for this malignant tumor [22], however, it possesses significant general toxicity in treated organism and, thus, should be used in combination with specific additives called adjuvant, in order to decrease its acting dosage.

\section{MATERIALS AND METHODS}

The greater celandine seeds were harvested in June, 2010-2011. Oil was obtained from the seeds, and sapogenin like substance (SLS) was purified, as described in [12].

A therapeutic effect of vinblastine (Gedeon Richter, Hungary) alone and in combination with isolated SLS was studied towards murine NK/Ly lymphoma (ascite form of tumor) which was obtained from the collection of tumor strains at R. E. Kavetsky Institute of Experimental Pathology, Oncology and Radiobiology, NAS of Ukraine (Kyiv). Tumors were transplanted as described $[22,25]$ by the intra-abdominal inoculation of ascite aliquots that contained $10 \mathrm{mln}$ tumor cells taken from the tumor-bearing animal on the $7-8^{\text {th }}$ day of tumor growth. In experiments were used C57 black mice, experiments were conducted in accordance with the requirements of the European Convention on protection of vertebrate animals (November 13, 1987) and The Law of Ukraine "On protection of animals from cruel behavior" (March 28, 2006).

Schemes of treatment. All solutions were prepared ex tempore and injected intraperitoneally the same day. For protection against the accidental infection, laevomycetine (50 $\mu \mathrm{g}$ per mouse) was added to injection solutions. This antibiotic was also used by other investigators [3,23] for alleviation of toxic effect of cyclophosphamide, but used doses were much more higher (20 mg per mouse ) comparing to those applied in our experiments. We found (data not shown) that laevomycetine in dose of $50 \mu \mathrm{g}$ per mouse had no effect upon the growth of NK/Ly lymphoma.

At treatment with vinblastine alone, the injection solutions were prepared in a sterile ampoule by the introduction $10 \mu \mathrm{l}$ of $0.2 \%$ solution of vinblastine sulfate in $50 \%$ alcohol, $20 \mu$ of $1 \%$ alcohol solution of laevomycetine, $0.8 \mathrm{ml}$ of sterile water. $0.2 \mathrm{ml}$ of this solution corresponding to $5 \mu \mathrm{g}$ of vinblastine and $50 \mu \mathrm{g}$ of laevomycetine for one animal was injected in days 1, 3, 7 after tumor cell inoculation (defined as day 0, see Fig.1).

During treatment with a combination of vinblastine and SLS, two solutions were prepared. The first one contained vinblastine and SLS prepared by placing $4 \mathrm{mg}$ of dry SLS in a small sterile round bottom tube, $20 \mu \mathrm{l}$ of $1 \%$ alcohol solution of laevomycetine

ISSN 1996-4536 • Біологічні Студії / Studia Biologica • 2012 • Том 6/№3 • С. 29-38 
that was minced with a glass rod to a uniform slurry. Thereafter, $10 \mu \mathrm{l}$ of $0.2 \%$ solution of vinblastine sulfate in $50 \%$ alcohol and $0.8 \mathrm{ml}$ of sterile water were added sequentially, which led to a complete dissolution of material and formation of colorless transparent solution. Care must be taken to mince well solid mass of SLS in order to achieve its rapid dissolution after addition of water. $0.2 \mathrm{ml}$ of this solution corresponding to $1 \mathrm{mg}$ of SLS, $5 \mu \mathrm{g}$ of vinblastine, and $50 \mu \mathrm{g}$ of laevomycetine for one animal was injected in days $1,3,7$, and occasionally also on the $11^{\text {th }}$ day after tumor cell inoculation. The second type of solution was prepared similarly with an exclusion of vinblastine, and was injected in days 3 and 6 after tumor cell inoculation.

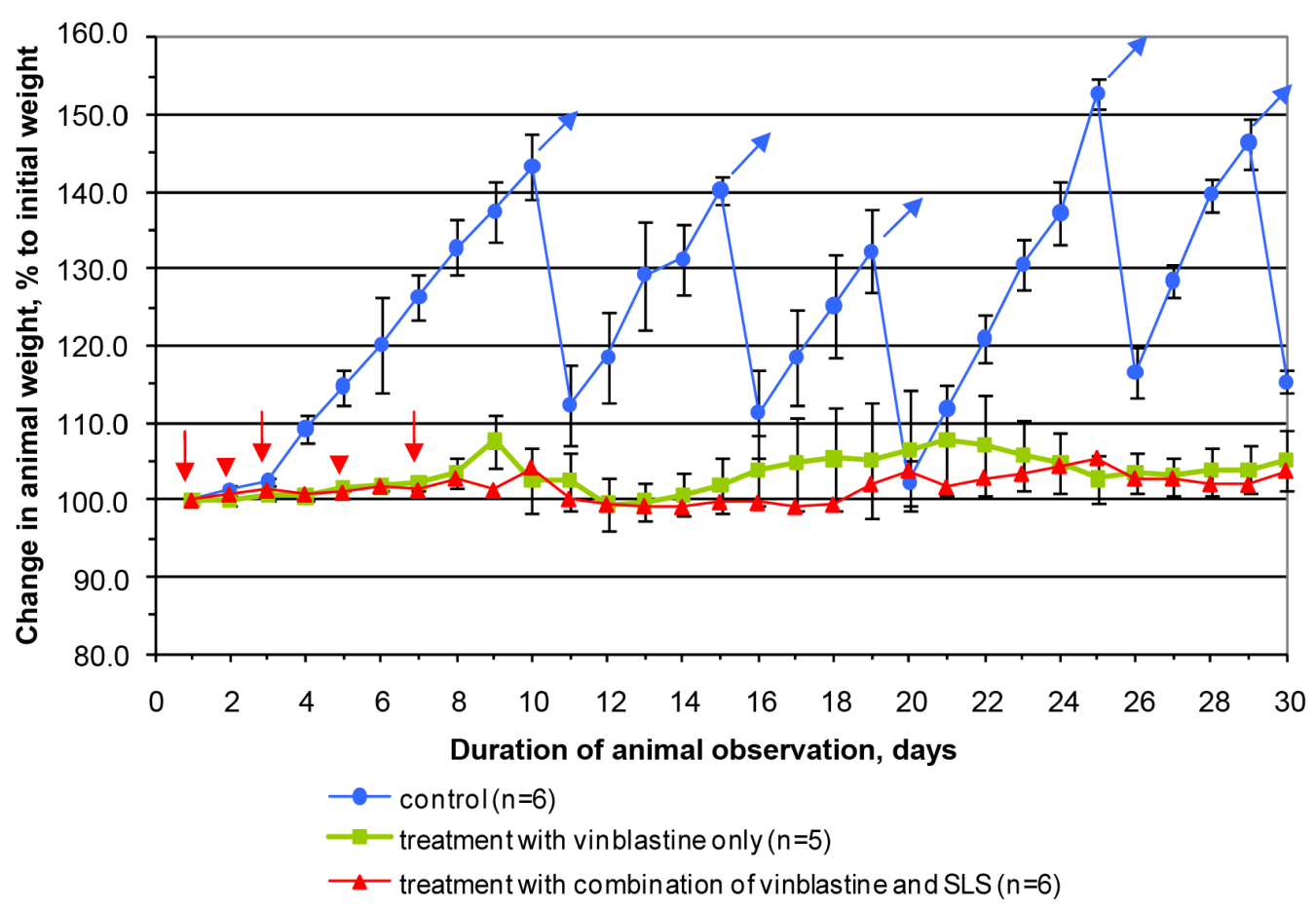

Fig. 1. Effect of treatment scheme upon the growth of murine NK/Ly lymphoma at the initial stage of tumor development:
$\nearrow$ - drainage of ascite (in control only);
$\downarrow \quad$ - intra-abdominal injection of vinblastine or vinblastine with SLS;
$\downarrow$ - intra-abdominal injection of SLS only

Рис. 1. Вплив схеми лікування на ріст мишиної лімфоми NK/Ly на початковій стадії розвитку пухлини:

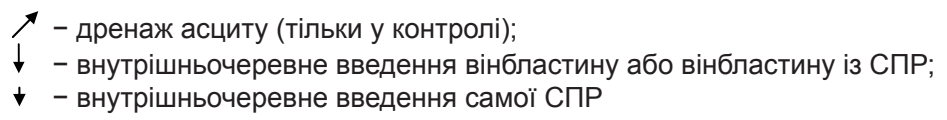

The efficacy of treatment was estimated according to clinical and cytological data. Clinical data included monitoring of body weight (every day for the first 30 days), time of survival, volume of ascite (in cases when it was developed and evacuated), and total number of tumor cells in it. Taking into account that vinblastine is a very effective drug and frequently leads to recovery, the stability of remission was checked by reinoculation 
of tumor cells after 40 days of experiment and the second reinoculation after 120 days. Treated mice were observed for a prolonged time (more then 120 days ) in order to reveal the effect of a combined application of vinblastine with SLS, as compared to vinblastine alone. Cytological data included a measurement of cell diameter by using special program AxioVision release 2007 (Karl Zeiss), and distribution of cell dimensions in population. The semithin sections of tumor cells were obtained after fixation of material in $2 \%$ glutaric aldehyde, processing and embedding in the Epon 812 resin according to recommendations of the manufacturer (Fluka Production $\mathrm{GmbH}$ ). 1-1.5 $\mu \mathrm{m}$ sections were processed on the ultramicrotome (LKB) and stained with safranin T or Gentian violet, as follows: $30-40 \mathrm{~min}$ in solution of $0.5 \%$ safranine $\mathrm{T}$ in $10 \mathrm{mM}$ tris or $15-20 \mathrm{~min}$ in freshly prepared solution of Gentian violet $(0.5 \mathrm{mg} / \mathrm{ml})$ in $25 \mathrm{mM}$ Tris. The areas of cell cytoplasm, nucleus and nucleoli were measured using the above mentioned AxioVision program. A proportion of damaged cells in their population was determined by counting of cytological smears stained with azure-eosine (Romanovsky-Giemsa method), bromophenol blue for protein [14], hematoxylin (for structure of nucleus and chromatin). Images from smears were taken with Canon A590 camera, and not less than 300 cells were counted on the images from every smear.

Statistical analysis. Significant difference between groups of data was estimated with the aid of Microsoft Office Excel 2003 program using Student's $t$ criterion, values of $\mathrm{P}<0.05$ were accepted as index of significant difference.

\section{RESULTS AND DISCUSSION}

Application of both schemes of treatment of murine NK/Ly lymphoma (vinblastine alone and vinblastine combined with SLS from greater celandine) resulted in practically identical picture of drugs' action at the initial stages (30 days) of tumor development (Fig. 1). That was probably due to high potency of vinblastine action. The animal body weight measurement curves reflecting tumor growth demonstrated in both cases an effective suppression of tumor growth.

However, significant differences between the effects of these treatment schemes were observed in more delayed terms ( $>60$ days and best expressed at around 200 days). The delayed consequences of treatment were checked after the re-inoculation of tumor cells in the remission period after the first course of chemotherapy. In five mice treated with a combination of vinblastine and SLS, the re-inoculation performed on the $43^{\text {rd }}$ day of the experiment, caused a renewal of tumor growth in all but one animal. All four mice treated with vinblastine have demonstrated the development of the ascite. Its evacuation and additional injections of vinblastin or vinblastin+SLS suppressed further tumor growth and led to a stable remission, except in one animal treated with vinblastine and which was found to be resistant to this drug. The second re-inoculation of tumor cells done in 130 days of the experiment, did not cause any renewal of the ascite growth.

The volume of the ascite and total number of cells in it were significantly reduced after the $1^{\text {st }}$ re-inoculation of tumor cells, as compared with the untreated (control) mice (Table 1). However, there was no statistically significant difference between these indicators at using two treatment schemes - vinblastine alone and vinblastine with SLS.

The duration of life can not be expressed in the mean values since in both groups (treated without and with SLS) several mice have completely recovered. They survived after all treatments and lived for more than 200 days without any signs of tumors. In the group of 5 mice treated with vinblastine alone, 2 mice survived, and in the group of

ISSN 1996-4536 • Біологічні Студії / Studia Biologica • 2012 • Том 6/№3 • С. 29-38 
6 mice treated with a combination of vinblastine and SLS, there were 4 mice that completely recovered. The death at late stages of the disease was caused by the appearance and slow growth of the nodes of solid tumors, especially in the pits of back limbs that led to animal exhaustion, paralysis of back limbs, or bleeding.

Table 1. Effect of treatment scheme upon the ascite volume and total number of cells in the ascite

Таблиця 1. Вплив схеми лікування на об'єм асциту і загальну кількість клітин у ньому

\begin{tabular}{l|c|c|c}
\hline \multicolumn{1}{c|}{ Treatment scheme } & $\begin{array}{c}\text { Number } \\
\text { of samples }\end{array}$ & $\begin{array}{c}\text { Volume of ascite, } \\
\mathrm{ml}(\mathrm{M} \pm \mathrm{m})\end{array}$ & $\begin{array}{c}\text { Total number of ascite } \\
\text { cells, } \times 10^{6}(\mathrm{M} \pm \mathrm{m})\end{array}$ \\
\hline Control $^{*}$ & 12 & $9.2 \pm 1.6$ & $1164 \pm 134$ \\
\hline Vinblastine $^{* *}$ & 6 & $3.8 \pm 0.6$ & $173.3 \pm 42.4$ \\
\hline Vinblastine combined with SLS $^{* *}$ & 9 & $5.4 \pm 0.7$ & $277.1 \pm 76.1$ \\
\hline
\end{tabular}

Comment: *ascite was taken 7-8 days after the initial tumor inoculation; **ascite was taken 7-9 days after delayed tumor re-inoculation and treatment as indicated. Highly significant difference $(P<<0.05)$ between control and treated animals, no significant difference between both schemes of treatment.

Примітка: *асцит забирали через 7-8 днів після початкової інокуляції пухлини; **асцит отримано через 7-9 днів після повторної інокуляції і лікування, як було зазначено. Вірогідна різниця $(\mathrm{P}<<0,05)$ між контрольними і лікованими тваринами, різниця між двома схемами лікування невірогідна.

Clinical picture of the applied treatment schemes suggests that SLS isolated from the greater celandine exhibits a positive effect in chemotherapy of murine NK/Ly lymphoma, when it is administered in the combination with vinblastine. However, that effect was expressed only in the delayed terms of observation of treatment consequences. We suggest that such enhancement of vinblastine action by the SLS might be caused by the prevention of development of solid tumor nodes which are less susceptible resp. more resistant to vinblastine action than the ascitic tumor cells.

The effect of applied treatments was also examined by the cytological studies of ascites obtained at 7-9 days after the first re-inoculation of tumor cells. In accordance with our previous observations [13], dimensions of lymphoma cells were greatly increased under the action of vinblastine. Here we detected even more pronounced effect on tumor cell dimensions under the combined action of vinblastine and SLS, comparing with the action of vinblastine alone (Table 2). The difference in size and intracellular structure of the enlarged (giant) and parental lymphoma cells is distinctly visible in the semi thin sections of these cells (Fig. 2). The data of cell morphometry (Table 3) demonstrate that giant transformation of the lymphoma cells induced by the vinblastine, is accompanied by the great expansion of cell cytoplasm in the expense of nucleus and nucleoli. This might be caused by a continuous synthesis of intracellular proteins, while the DNA replication process is arrested.

Cell damage induced by the treatment under two schemes was evaluated by examination of cytological smears stained by azure-eosin after Romanovsky-Giemsa method, bromophenol blue dye for cell proteins, and hematoxylin detecting the structure of nucleus and chromatin.

As expected, vinblastine application in both treatment schemes caused a pronounced damage of tumor cells, compared to control (untreated) mice (Table 2). However, the indices of cell damage did not differ significantly between the compared treatment schemes, 
except cell diameter, which was the highest at combined vinblastine-SLS treatment. Indices of cell damage based on evaluation of protein content were much lower than such indices counted after using other staining methods. Many giant cells possessed normal or even increased protein level and, thus, were not registered as damaged, while according to the results of using other methods of study, these cells differed significantly from typical parental cells by their shape, dimensions, presence of cytoplasm vesicles and other inclusions, and, thus, were considered as damaged.

\section{Table 2. Effect of treatment scheme upon morphological characteristics of murine NK/Ly} lymphoma cells

Таблиця 2. Вплив схеми лікування на морфологічні характеристики клітин мишачої лімфоми NK/Ly

\begin{tabular}{l|c|c|c|c|c}
\hline & \multirow{2}{*}{$\begin{array}{c}\text { Treatment scheme } \\
\text { (animal number) }\end{array}$} & $\begin{array}{c}\text { Mean of cell } \\
\text { diameter (D) } \\
\mu \mathrm{m}\end{array}$ & $\begin{array}{c}\text { \% of cells } \\
\mathrm{D}>18 \mu \mathrm{m}\end{array}$ & \multicolumn{3}{|c}{$\%$ of damaged cells in population } \\
\cline { 4 - 6 } & & $\begin{array}{c}\text { Azure- } \\
\text { eosin }\end{array}$ & $\begin{array}{c}\text { Bromo- } \\
\text { phenol blue }\end{array}$ & Hematoxylin \\
\hline $\begin{array}{l}\text { Control (no treatment) } \\
(\mathrm{n}=12)\end{array}$ & $13.6 \pm 0.3$ & $6.3 \pm 1.2$ & $26.8 \pm 3.9$ & $8.5 \pm 1.5$ & $13.2 \pm 1.2$ \\
\hline $\begin{array}{l}\text { Vinblastine } \\
(\mathrm{n}=5)\end{array}$ & $22.4 \pm 0.4$ & $89.4 \pm 3.4$ & $88.2 \pm 3.2$ & $33.3 \pm 2.5$ & $81.9 \pm 4.3$ \\
\hline $\begin{array}{l}\text { Vinblastine in combination } \\
\text { with SLS ( } \mathrm{n}=6)\end{array}$ & $25.4 \pm 0.4$ & $95.0 \pm 3.1$ & $95.0 \pm 4.3$ & $37.6 \pm 2.1$ & $90.5 \pm 4.5$ \\
\hline
\end{tabular}

Comment: All indices differ significantly between control and treated animals $(P<<0.05)$, in two compared schemes of treatment the significant difference in cell diameter only was observed $(P<0.05)$.

Примітка: вірогідна відмінність між усіма показниками контрольних і лікованих тварин $(P<<0,05)$, між двома порівнюваними схемами лікування вірогідна різниця спостерігалась лише за діаметром клітин $(P<0,05)$.
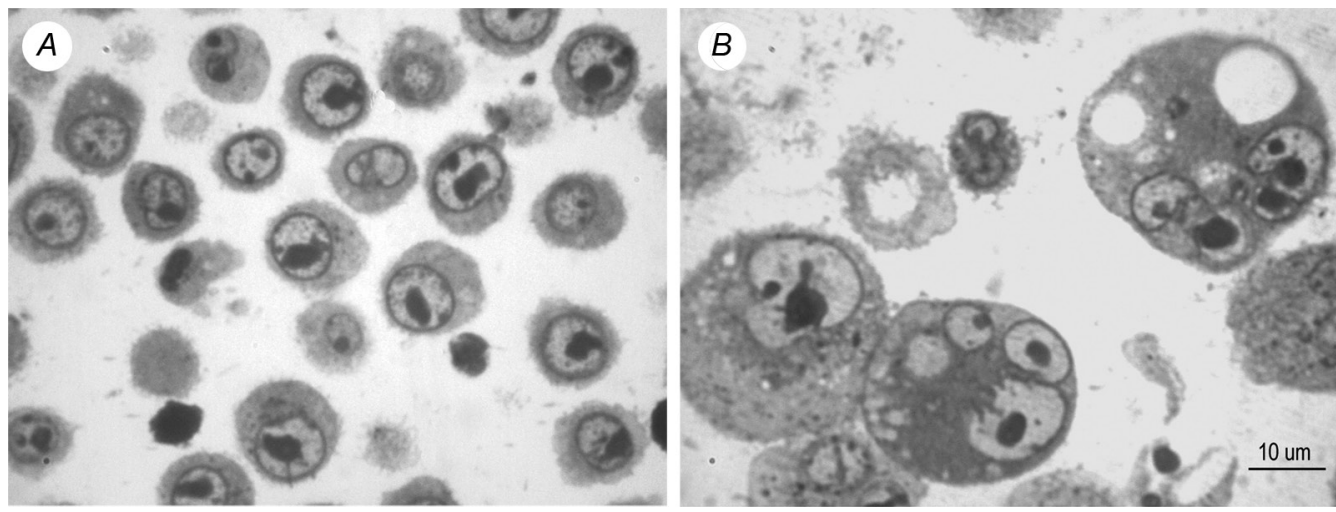

Fig. 2. Semithin sections $(1.5 \mu \mathrm{m})$ of murine NK/Ly lymphoma cells.

$A$ - parental cells taken from control animals at the $8^{\text {th }}$ day of tumor growth; $B$ - giant transformed cells induced by treatment with vinblastine or a combination of vinblastine with SLS. Staining with safranin $\mathrm{T}, 60 \times 15$

Рис. 2. Напівтонкі зрізи (1,5 мкм) клітин мишиної лімфоми NK/Ly.

$A$ - батьківські клітини, одержані від контрольних тварин на 8-й день росту пухлини; $B$ - гігантські клітини, які утворюються під час лікування вінбластином або комбінацією вінбластину зі СПР. Фарбування сафраніном T, $60 \times 15$

ISSN 1996-4536 • Біологічні Студії / Studia Biologica • 2012 • Том 6/№3 • С. 29-38 
An important advantage of the SLS isolated from the greater celandine is its very low general toxicity that is an additional argument in favor of its application in combination with a powerful anticancer agent vinblastine, a well known anticancer drug. A single intraperitoneal injection of $6 \mathrm{mg}$ of SLS to mouse (corresponds to $300 \mathrm{mg} / \mathrm{kg}$ of body mass) did not cause animal death or visible change in behavior.

These data prompt a perspective search for new saponin/sapogenin-like substances possessing low toxicity and considerably enhancing the curative effect of known chemotherapeutic drugs. As the example could be dammarane sapogenins of ginseng (Panax ginseng C. A. Meyer) [5, 6], however, there are many other medicinal plants containing saponins that are poorly studied. According to the reports of Natural Products Branch of the National Cancer Institute (USA), since 1960, only seven plant-derived anticancer drugs have been approved for commercial production by the Food and Drug Administration (FDA) [20]. Recently, this situation has been improved, as some new anticancer substances were isolated from various natural products, including plants [1].

Table 3. Correlation between the areas of cytoplasm, nucleus, and nucleoli in the parental and giant murine NK/Ly lymphoma cells

Таблиця 3. Співвідношення між площами цитоплазми, ядра та ядерець у батьківських і гігантських клітинах мишачої лімфоми NK/Ly

\begin{tabular}{l|c|c|c}
\hline \multirow{2}{*}{\multicolumn{1}{c|}{ Lymphoma cell type }} & \multicolumn{3}{|c}{ Area of cell compartment $(\%$ of $100 \%)$} \\
\cline { 2 - 4 } & Cell cytoplasm & Nucleus & Nucleoli \\
\hline Parental cells $(\mathrm{n}=20$ cells) & $52.7 \pm 1.5$ & $37.8 \pm 1.3$ & $8.6 \pm 0.7$ \\
\hline Giant cells $(\mathrm{n}=12$ cells) & $68.5 \pm 1.7^{*}$ & $25.9 \pm 1.6^{*}$ & $5.0 \pm 0.8^{*}$ \\
\hline
\end{tabular}

Comment: *statistically significant difference $(\mathrm{P}<0.05)$ between giant and parental cells.

Примітка: *статистично вірогідна різниця $(P<0,05)$ між гігантськими і батьківськими клітинами.

Regarding potential mechanisms of action of the SLS isolated from the greater celandine, we suppose that they might target and inhibit plasma membrane P-glycoprotein based transporting system which can expel from the cell foreign substances, including drugs. Such action was shown for the dammarane sapogenins [5, 7].

\section{CONCLUSION}

Sapogenin-like substance isolated from the greater celandine seeds possess low general toxicity and demonstrates a favorable effect upon the curative action of vinblastine used for treatment of murine NK/Ly lymphoma. The potentiating effect of substance is manifested distinctly in a delayed results of tumor treatment ( $>60$ days) by the vinblastine. The obtained results suggest that sapogenin-like substance of the greater celandine might be considered as a perspective adjuvant when applied in a combination with routine anticancer drugs.

1. Anticancer agents from natural products. Second edition / Ed. G. Cragg, D. Kingston, D. Newman. CRC Press, 2011. 767 p.

2. Bang S.-Ch., Lee J.-H., Song G.-Y. et al. Antitumor activity of Pulsatilla koreana saponins and their structure-activity relationship. Chem. Pharm. Bull, 2005; 53(11); 1451-1454.

3. Bogush T.A. Effect of chloramphenicol on toxic and therapeutic action of cyclophosphane. Antibiot. Med. Biotechnology, 1986; 31(3); 199-202. 
4. Colombo M., Bosisio E. Pharmacological activities of Chelidonium majus L. (Papaveraceae). Pharmacol. Research, 1995; 33(2); 127-134.

5. Dammarane sapogenins. Novel nontoxic anti-cancer agents, 2007. http://j. b5z.net/i/u/2100778/i/Bi_Eng_May_2007.pdf

6. Dong Huang, Dong Feng Qi Novel aglycon dammarane sapogenins, their use as anti-cancer agents, and a process for producing same. US Patent, US 2003/0087835 A1.

7. Jia W., Yan H., Bu X., Liu G., Zhao Y. Aglycone Protopanaxadiol, a ginseng saponin, inhibits P-glycoprotein and sensitizes chemotherapy drugs on multidrug resistent cancer cells. ASCO Annual Meeting Proceedings. J. Clin. Oncol, 2004; 22(14 S) Abstr. \#9663.

8. Kaminskyy V.O., Lootsik M.D., Stoika R.S. Correlation of the cytotoxic activity of four different alkaloids from Chelidonium majus (Greater celandine), with their DNA intercalating properties and ability to induce breaks in the DNA of NK/Ly murine lymphoma cells. Centr. Eur. J. Biol, 2006; 1(1): 2-15

9. Kaminskyy V., Kulachkovskyy O., Stoika R. A decisive role of mitochondria in defining rate and intensity of apoptosis induction by different alkaloids. Toxicol. Lett, 2008; 177(3): 168-81.

10. Kwasniewski V. Uber die Auffindung eines Saponins im Schollkraute, Chelidonium majus L. Archiv der Pharmazie, 1958; 63(4); 209-211.

11. Liu M.J., Wang Z., Wong R.N., Wu Q.Y. Diosgenin induces cell cycle arrest and apoptosis in human leukemia $\mathrm{K} 562$ cells with the disruption of $\mathrm{Ca}^{2+}$ homeostasis. Cancer Chemother. Pharmacol, 2005; 55(1); 79-90.

12. Lootsik M., Boiko N., Lutsyk M.(Jr.), Stoika R. Purification of sapogenin from seeds of Greater celandine (Chelidonium majus L.) and investigation of its influence towards experimental lymphoma NK/Ly. Proc. Shevchenko Sci. Soc. Chem. Biochem, 2011; 28; 150-159.

13. Lutsik M.D., Boiko N.M., Lutsyk M.M. Studies of therapeutic effect of saponin from Great celandine on a model of murine lymphoma NK/Ly. Abstracts of the $2^{\text {nd }}$ Ukrainian Congress for Cell Biology, Kyiv, 2007; 103.

14. Lutsyk M.M., Yashchenko A.M. Quantitative method of evaluation of tumor cells damage under the influence of antitumor drugs in vivo by cytochemical staining for protein. Reports of Morphology (Visnyk Morfologii), 2009; 15(1): 188-92. (in ukr.).

15. Mazn'ev N.I. Greater celandine, Hellebore and other natural curatives of the family. M.: Ripol classic Ltd, 2005; 256 р. (Мазнев Н.И. Чистотел, морозник и другие природные целители семьи. М.: ООО ИД „Рипол классик”, 2005. 256 с.).

16. Ovesna Z., Vachalkova A., Horvathova K., Tothova D. Pentacyclic triterpenoic acids: a new chemoprotective compounds. Neoplasma, 2004; 51(5); 327-333.

17. Ouyang X., Yu Z., Chen Z. et al. A pilot study of safety and efficacy of pandimex with or without paclitaxel in the treatment of advanced solid tumors. ASCO Annual Meeting Proceedings. J. Clin. Oncol, 2005; 23(16 S), Abstr. \#3188.

18. Panagin Pharmaceuticals Inc. Oral Bioavailability Enhancement Technology (OBET). http://www.panagin.com

19. Potopalsky A.I. Preparations of Greater celandine in biology and medicine. Kiev: Naukova dumka, 1992. 237 р. (Потопальский А.И. Препараты чистотела в биологии и медицине. Киев: Наук. думка,1992. 237 с.).

20. Questions and answers about NCl's Natural Products Branch. What is the Natural Products Branch and what are its goals? http://cis.nci.nih.gov/fact/7_33.htm

21. Raju J., Mehta R. Cancer chemopreventive and therapeutic effects of diosgenin, a food saponin Nutr. Cancer, 2009; 61(1); 27-35.

22. Sellei C., Eckhardt S., Nemeth L. Daganatos betegsegek gyogyszeres kezelese (Drug treatment of tumor diseases). Budapest: Akademiai Kiado, 1975; 21-23 (Hungarian and Russian editions).

23. Shabad L.M., Bogush T.A., Belitsky G.A. On the influence of chloramphenicol on the induction of lung adenomas by urethane in mice. Neoplasma, 1975; 22(4); 347-354.

24. Shoji Shibata. Chemistry and cancer preventing activities of Ginseng saponins and some related triterpenoid compounds. J. Korean Med. Sci, 2001; 16 (Suppl.); S28-S37.

ISSN 1996-4536 • Біологічні Студії / Studia Biologica • 2012 • Том 6/№3 • С. 29-38 
25. Experimental evaluatuion of antitumor preparations in USSR and USA / Ed. Z.P. Sofyina, A.B. Syrkin, (USSR), A. Goldin, I. Klein (USA). Moscow: Medicina, 1980. 295 p.

26. Taborska E., Bochorakova H., Dostal J., Paulova H. The greater celandine (Chelidonium majus L.) - review of present knowledge. Ceska Slov. Farm, 1995; 44(2); 71-75.

27. Yan L.L., Zhang Y.I., Gao W.Y. et.al. In vitro and in vivo anticancer activity of steroid saponins of Paris polyphylla var.Yunnanensis. Exp. Oncol, 2009; 31(1); 27-32.

\title{
САПОГЕНІНИ I3 НАСІННЯ ЧИСТОТІЛУ (Chelidonium majus L.) ПОТЕНЦІЮЮТЬ ТЕРАПЕВТИЧНУ ЕФЕКТИВНІСТЬ ВІНБЛАСТИНУ СТОСОВНО МИШАЧОÏ ЛІМФОМИ NK/LY
}

\author{
М. Д. Луцик', М. М. Луцик², Р. С. Стойка' \\ 1 Інститут біології клітини НАН України, вул. Драгоманова, 14/16, Львів 79005, Україна \\ 2 Львівський національний медичний університет ім. Данила Галицького \\ вул. Пекарська, 69, Львів 79010, Україна
}

Проведено порівняльне дослідження терапевтичної ефективності двох схем лікування мишачої лімфоми NK/Ly - внутрішньочеревним введенням вінбластину і комбінації вінбластину зі сапогеніноподібною речовиною (СПР), очищеною із насіння чистотілу. Встановлено, що на ранній стадії росту пухлини гальмівна дія обох схем лікування достовірно не відрізнялась. Потенціювальна дія СПР при комбінованому застосуванні із вінбластином проявлялась у віддалених результатах лікування, через 60 і більше діб після інокуляції пухлинних клітин. Клінічно це проявлялось у більш ефективному пригніченні розвитку пухлини після повторної інокуляції пухлинних клітин, у запобіганні появі солідних вузлів пухлини, у кращих показниках одужання і виживання мишей, лікованих за другою схемою. Кількісна оцінка пошкодження пухлинних клітин за допомогою морфометричних методів виявила вищий ступінь пошкодження у разі застосування комбінації вінбластин-СПР. Низька токсичність СПР із насіння чистотілу при одночасному підсиленні лікувальної дії вінбластину дає підстави припускати перспективність застосування СПР як ад'юванта при хіміотерапії пухлин.

Ключові слова: чистотіл, сапогеніни, вінбластин, лімфома NK/Ly, лікування.

\section{САПОГЕНИНЫ ИЗ СЕМЯН ЧИСТОТЕЛА (Chelidonium majus L.) ПОТЕНЦИРУЮТ ТЕРАПЕВТИЧЕСКУЮ ЭФФЕКТИВНОСТЬ ВИНБЛАСТИНА ПРИ ЛЕЧЕНИИ МЫШИНОЙ ЛИМФОМЫ NK/Ly}

\begin{abstract}
М. Д. Луцик', М. М. Луцик', Р. С. Стойка ${ }^{1}$
${ }^{1}$ Институт биологии клетки НАН Украины, ул.Драгоманова, 14/16, Львов 79005, Украина

2 Львовский национальный медицинский университет им. Даниила Галицкого ул. Пекарская, 69, Львов 79010, Украина

Проведено сравнительное исследование терапевтической эффеектвности двух схем лечения мышиной лимфомы NK/Ly - внутрибрюшинным введением винбластина и комбинации винбластина с сапогениноподобной субстанцией
\end{abstract}


(СПС), очищенной из семян чистотела. Установлено, что на ранней стадии роста опухоли угнетающее действие обеих схем лечения достоверно не различалось. Потенцирующее действие СПС при комбинированном применении с винбластином проявлялось в отдаленных результатах лечения, через 60 и более суток после инокуляции опухолевых клеток. Клинически это проявлялось в более эфффективном угнетении развития опухоли после повторной инокуляции опухолевых клеток, в предупреждении появления солидных узлов опухоли и в лучших показателях выздоровления и выживання мышей, леченных по второй схеме. Количественная оценка повреждения опухолевых клеток с помощью морфометрических методов выявила более выраженное повреждение клеток в случае комбинированного применения винбластина и СПС. Низкая токсичность СПС из семян чистотела при одновременном усилении лечебного действия винбластина позволяет предполагать перспективность применения СПС чистотела в качестве адьюванта при химиотерапии опухолей.

Ключевые слова: чистотел, сапогенины, винбластин, лимфома NK/Ly, лечение.

Одержано: 18.10 .2012

ISSN 1996-4536 • Біологічні Студії / Studia Biologica • 2012 • Том 6/№3 • С. 29-38 